\title{
Introduction to the World of International Women Entrepreneurs
}

\author{
Dr. Andrea Smith-Hunter \\ Professor of Management \\ Siena College, 515 Loudon Road \\ Loudonville, NY 12211, (518)782-0220 \\ Ahunter@siena.edu
}

\author{
Dr. JoAnne Kapp \\ Associate Professor of Management \\ Siena College, 515 Loudon Road \\ Loudonville, NY 12211, (518)783-4262 \\ KAPP@siena.edu
}

\section{Dr. James Nolan}

Professor of Quantitative Business Analysis

Siena College, 515 Loudon Road

Loudonville, NY 12211, (518)783-4086

jnolan@siena.edu

\section{INTRODUCTION}

The last century has seen phenomenal advances in women's societal position, both from an educational, as well as economic perspective. At the turn of the previous century, women's position was dominated by "feminine" characteristics, that resulted in them being "gendered" and primed in their roles as wives, mothers, caretakers - albeit women. These characteristics were displayed in various facets as housewives, unequal partners - a home setting and often an unpaid employee, under-rewarded partner if they assisted in the operation of a business alongside their husbands.

Since the 1900s, there have been a number of historical events that have reconfigured the landscape for women's position from a societal or labor market perspective. Specifically, the Depression Era of the 1930s and the follow up World War II period forced women's initial entry into the labor market arena. In the former case, the purpose was to supplement the family's income and improve the chances of basic survival of the members. In the latter case, the purpose was to replace their male counterparts who were absent from the labor market, because they were fighting a prolong and extensive War. Later, revolutionary actions, such as the Civil Rights Movement, the Labor Movement and the Women's Movement that were instigated in the United States, but whose influence mushroomed in other parts of the world, led to women engaging in mass numbers in the educational, political, societal and labor market arenas. This engagement has changed the positioning of women and their roles on a societal level.

In spite of the previously mentioned changes, women continue to occupy a differential space in relation to men worldwide. This differential occurs at different levels and is related to the quality of health, the level of education, the family gender roles, their position in the labor market and the overall sharing of power, resources and social positions in the wider society. From an in-depth perspective, a critical question that can be posed is where do women stand in today's society? The rest of the paper provides worldwide figures in critical statistics for women, detailing their mortality rates, life expectancy rates and health figures. The overall goal is highlighted in how this impacts and is impacted by women's involvement in the labor market. These figures are presented across several countries and by industry. The reader is then provided with the framework to assess women's position in the world of entrepreneurship on a global level.

The primary purpose of this paper is to provide a comprehensive look at women in today's environment - doing so from social, political and economic perspective. To that end, the discussion starts from the conviction of women's current position in various sectors and openly questions the adequacy of the current actions on a national and international platform, highlighting their inefficiencies in moving women's position forward to a place of equality. Women are being 
increasingly recognized as legitimate income earners in today's society. However, their negative health, societal and political forces, act as barriers to sustainable development for women's work related efforts and have not always been addressed (Odey, 2015). The paper is written from a constructive perspective, highlighting some good practices that have been instituted worldwide but questions the legitimacy of others. One feature that is used to build much of the presentation in this paper is statistical data. Data that again takes a three-prong approach -societal, political and economic - and details the current status of females worldwide from these perspectives.

The paper also outlines the path that the rest of the paper will follow, providing brief synopses of each paper and what they will cover. The goal of this paper is multilayered. First, for women entrepreneurs it provides a picture of what is taking place with their counterparts in other sections of the world. Second, for government agencies and organizations that see women entrepreneurs as their customers, it provides a perspective of what some of their needs are, allowing such organizations to become attuned to what can be done to facilitate and address the concerns for women entrepreneurs. Third, for countries worldwide, the goal is to provide some documentation of the impact that women entrepreneurs are providing to an economy and the related multiplier effect that results from their participation in deriving an income. Fourth, for international organizations that strive to solve issues of gender inequality, women's disadvantaged position in various sectors of society, the hope is that they will see entrepreneurship for women as a feasible and concrete solution that can solve these crosscutting challenges. Feasible and concrete since by its very nature, entrepreneurship can be built on an owner's natural talent, with limited initial funds, with heavy reliance on volunteer efforts to supplement and assist where needed. Fifth, with the feminine face that is often linked to poverty, the hope is that entrepreneurship by women, especially in mass numbers, will in turn solve other social ills that have long existed in society because of women's deteriorating position. This is possible since women entrepreneurs are more likely than others to employ day laborers or part-time workers who may be on the periphery of the mainstream labor market and less likely to work in this arena.

The attack on the feminine nature of poverty is important, since it is only by allowing women more access to productive resources such as land, credit, education, training, improved health and remunerated employment can thus have a negative association with poverty be halted and eventually reversed. Some agencies see poverty reduction as critical in arresting the other social, political and economic issues that plague women in most societies (Bahmani et al, 2012; Browne, 2001; Dana, 2015). They indicate that the main reason why some countries remain mired in poverty and underdevelopment while others progress, lie in the various positions women occupy in that society (Ababa, 2005; Riphenburg, 2004). Specifically, Riphenburg (2004) explained that when women gain equal education and power in a society, birth rates have been shown to fall and food supplies increase, resulting in economic development and stability to that society. This education is particularly important at a secondary and tertiary level where the acquisition at this level is more likely to increase one's wealth and standard of living (Diochon, 2015; Fleming, 2015; Gallagher and Lawrence, 2012). Educational attainment is significant, since level of schooling has been said to be linked to rates of labor market participation for women (Gurman et al, 2105; Hokari, 2013; Kumar, 2015). In fact the vicious cycle between education and income, shows that there is a positive correlation between levels of education and income earning. That is, higher levels of income open opportunities to higher levels of education and in turn, higher levels of education ultimately lead to higher income

Women who are able to earn a paid living or gain economic improvements through the positioning of their labor contribution to the marketplace are in a better place to assist the economy in which they live. Through entrepreneurship, there exists the possibility to arrest the burgeoning rate of poverty for women and thus their children. This is possible since entrepreneurship as an income earning source, offers women the opportunity and flexibility to earn an income while also performing child care and other household responsibilities. These responsibilities have been shown to be more likely to be affixed to women and seen as female work. For females worldwide, acquiring their own wealth is critical to uplifting their stand alone position in a society, since some societies are still more likely to have the fathers of households being the owners of wealth, wealth that is often passed on to their sons and not their daughters - this is sometimes done literally with such sons taking over their fathers' businesses. In some Asian countries, women's labor market experience is treated in stark contrast to that of men's, with both genders being exposed to two different tracks in the labor market, with the women's movement through the labor market, being known as the "mommy track", based solely on their female status, whether or not they were married and intended to have kids (Karachi et al, 1996). 


\section{LITERATURE REVIEW OF WOMEN ENTREPRENEURS}

A retrospective article by Mac Rae (2005) a few years ago identified the difficulties that women still struggle with in today's society. These issues include sub-par health, education and work options, including the glass ceiling and sexual harassment (Mac Rae, 2005). The author contends that entrepreneurship offers an outlet for women because of the disadvantages they face in the mainstream labor market but concede that they also face difficulties in this latter world as well, including the recipients of unpaid labor (Mac RAe, 2005). The author further points out that race; gender and socioeconomic statuses of women worldwide are factors that in turn determine their health status.

Recent papers that have looked at women entrepreneurs from unusual or often understudied backgrounds include that by Achtenhagen et al (2013); Al-Sadi et al (2013), Cheragi et al (2014); Hoque et al (2015); Iakovleva (2014); Lindvert (2015) and Mahmood et al (2013); Maru et al (2013); Misango et al (2013); N-Anantharaman (2013); Nwoye (2013); Ramadani et al (2013); Roomi (2013); Shankar (2013); Subramanian et al (2015); Welsh (2014).

Achtenhagen et al (2013) directed attention to recent research on women's entrepreneurship, focusing on Nordic countries. The paper encouraged research that investigated how context, at the micro, meso and macro level, is related to women's entrepreneurship, and acknowledged that gender is socially constructed. The paper found evidence that recent calls for new directions in women's entrepreneurship research are being followed, specifically with regard to how gender is done and how context is related to women's entrepreneurial activities (Achtenhagen et al, 2013). The purpose of a less recent paper by Berner et al (2012) was to direct attention to recent research on women's entrepreneurship, again focusing on Nordic countries. The paper encouraged research that investigated how context, at the micro, meso and macro level, is related to women's entrepreneurship, and acknowledges that gender is socially constructed. The authors found evidence that recent calls for new directions in women's entrepreneurship research are being followed, specifically with regard to how gender is done and how context is related to women's entrepreneurial activities.

Al-Sadi et al (2013) recognized the presence of some self-motivated women entrepreneurs in Oman, the study identified the barriers that they confront and highlighted the challenges that are needed to boost entrepreneurship. The study aimed to find the factors inhibiting women entrepreneurship in the Al-Batinah region of Oman, focusing on women entrepreneurs especially from the small and medium scale enterprises (Al-Sadi et al, 2013). It illustrated and focused on women entrepreneurship in Oman how theyare developing and expanding in numbers and types of industries (Al-Sadi et al, 2013). Finally, the study discussed the usual obstacles these women entrepreneurs faced including stereotypes and financial access and suggested some measures for improvement in the role of women entrepreneurs (Al-Sadi et al, 2013). Overall, they study was important as it added to the literature on entrepreneurship, especially in the context of socio-cultural aspects and the Islamic Arab world, where the literature is still scant.

Cheragi et al (2014) proposed in their research paper that an entrepreneur's expectation is influenced by the entrepreneur's attributes, but felt that expectation was also embedded in the micro-environment of networking and the macro-environment of culture. The authors felt that traditional culture and secular-rational culture differ in roles for women, which they felt influenced women entrepreneurs' networking and expectations (Cheragi et al, 2014). Their design compared cultures, with data from three traditional societies, Algeria, Morocco and Tunisia and two secular-rational societies, France and Belgium, surveyed in the Global Entrepreneurship Monitor, randomly sampling 39,336 women, including 2,306 entrepreneurs. Their analyses showed that women entrepreneurs have growthexpectations based on their background and increased by their competence and opportunity-motive, which also promoted business networks around their firms (Cheragi et al, 2014). Formation of expectations was embedded in the networks in the way that networking increased expectations. Formation of expectations is embedded in culture in the way that, surprisingly, expectations are higher in traditional culture than in secular-rational culture (Cheragi et al, 2014).

Hoque et al (2015) stated in their research paper on Bangladesh that country's leaders envisioned a situation for it to become a Middle Income Country by 2021. Women entrepreneurs' development and their contribution to the economy have long been considered one of the accelerating contributor in the Small and Medium Enterprises (SMEs) and economic growth. The authors undertook the study to explore the supportive factors which promoted and developed the women entrepreneurs in SMEs and 
demonstrated linkages with institutional and policy framework (Hoque et al, 2015). A mixed research methods was applied, including review of literature, key informant interviews, and focus group discussions. The study explored supportive factors which directly contributed to the women entrepreneurs' promotion and development in SMEs. It also demonstrated that the factors have linkages with institutional structure and the national policy framework (Hoque et al, 2015). The authors found that entrepreneurial education and motivational training, accessibility and availability of finance, institutional capacity, product profiles, diversification and modernization, marketing opportunities, networking, legal and regulatory environment and access to infrastructure and information were key supportive factors (Hoque et al, 2015).

Iakovleva's 2014 paper studied female entrepreneurship in two post-Soviet countries - Russia and Ukraine. Employing institutional theory, the research investigated the entrepreneurial environment, particularly government support programs and the availability of financial resources, with a focus on women entrepreneurs. The research was a qualitative investigation that consisted of 60 interviews with Russian and Ukrainian entrepreneurs, bank officers and representatives of government organizations supporting the development of entrepreneurship. The investigation provided evidence that these countries have overcome the transition from a command to a market economy and local people are gradually adjusting to the new environment. Concentrating on macro/meso and money elements from the 5M model the authors suggested an additional construct - "motherland" - to embed a context in a new model on what contributes to the success of women entrepreneurs (Iakovleva, 2014).

The aim of the research by Mahmood et al (2013) was to examine the mediating effect of competitive advantage on the relationship between entrepreneurial orientation and performance of women-owned SMEs in Malaysia. It proposed a quantitative analysis in which entrepreneurial orientation and sources of competitive advantage are key success factors of SMEs. To answer the research questions, two hypotheses were formulated; (a) There is significant relationship between entrepreneurial orientation and business performance, and (b) competitive advantage mediates the relationship between entrepreneurial orientation and performance. Data were collected by means of a mail survey questionnaire completed by women owner/managers randomly selected from a sampling frame of registered SMEs.The questionnaires developed from prior research were used to measure the entrepreneurial orientation and competitive advantage of the firm while performance measurement was based on subjective evaluation involving self- reported measures. The findings revealed that significant relationships exist between entrepreneurial orientation and performance, while competitive advantage was found to partially mediate the entrepreneurial orientation and performance relationships (Mahmood et al, 2013). These findings may be of help to the women owner/managers of SMEs to be more entrepreneurial oriented and developed competitive edge in order for them to survive the intensely competitive market environment (Mahmood et al, 2013).

Maru et al in their 2013 study looked at Microfinance Institutions (MFIs), who provided their members with financial and social intermediation services to help improve their businesses. Despite a multitude of studies devoted to the topic, the effect of microfinance intervention on the empowerment of women entrepreneurs in rural constituencies remains largely unexplored in Kenya. Their paper sought to bridge the gap by establishing the effect of microfinance interventions on empowerment of women entrepreneurs in Mogotio Constituency in Kenya. It focused on three specific objectives to: determine the effect of micro credit on empowerment of women entrepreneurs, examine the effect of micro savings on empowerment of women entrepreneurs and, finally establish the effect of training on empowerment of women entrepreneurs. The paper adopted a causal survey research design through which 80 members of microfinance institutions (MFIs) in the study area were selected and data collected from them using a structured questionnaire. Linear multiple regression was used to determine the MFI intervention constructs that affected micro finance intervention. SPSS was used to generate the frequency distribution. Results showed that except for microfinance saving, other MFI interventions such as microfinance credit and microfinance training significantly and positively affect empowerment of women entrepreneurs (Maru et al, 2013). The study also made policy recommendations to guide development of microfinance interventions that are beneficial to the clients and other stakeholders of the MFI institutions (Maru et al, 2013).

Misango et al (2013) also examined women entrepreneurs in Kenya. The examined the economic role of women entrepreneurs in poverty reduction in Kenya. A case study was carried out among women entrepreneurs at the Maasai market within Nairobi City's Central Business District. From the target 
population of $664,15 \%$ were sampled for this study, through stratified and purposive sampling techniques. Quantitative and qualitative data were collected by use of questionnaires and interviews, hence analyzed concurrently. The study showed that the economic activities carried out by the respondents were similar in nature and included selling of African artifacts, clothing and ornaments. Most respondents (95\%) used readily available raw materials to make their products for sale (Misango et al, 2013). Majority of the respondents (83\%) agreed that the businesses had made them improve their economic status (Misango et al, 2013). The businesses contributed to the promotion of tourism, employment and export trade (Misango et al, 2013). The study concluded that women entrepreneurs play a major role in poverty reduction in Kenya (Misango et al, 2013).

Other papers on women entrepreneurs in Africa include those from: N-Anantharaman (2013); Nwoye (2013); Ramadani et al (2013); Shankar (2013); Lindvert (2015).

N-Anantharaman (2013) felt that entrepreneurship has been observed as one of the important factors that help to lift the economy of a nation. Due to the fact that women play an equal role in the development of a country, their study aimed to identify the environmental, personality and motivational factors that may lead to entrepreneurial decision. A comparison of these three factors is studied among women entrepreneurs in Small and Medium Enterprises (SMEs) with women nonentrepreneurs. The study was based on a questionnaire survey and the results indicated that there is a significant difference in environmental, personality and motivational factors among women entrepreneurs and non-entrepreneurs (N-Anantharaman, 2013). The environmental factors found psychological support, benefit from environment, and previous work condition as significant predictors of women entrepreneurship while the nine significant personality differences observed in the study were that the entrepreneurs portray more reasoning skills, emotional stability, vigilance and abstractness (N-Anantharaman, 2013). Apart from that, entrepreneurs were also found to have more privateness, high openness to change, perfectionism, more tension and less liveliness $(\mathrm{N}$ Anantharaman, 2013). Finally, for motivation factors, results revealed that individual core is not a significant predictor of women entrepreneurship (N-Anantharaman, 2013).

Nwoye (2013)felt that growth and development are among the most exciting subjects in economics, and the application of their principles to developing countries especially the African economies, is both needed and timely. In Nigeria, women have historically been disadvantaged in accessing not only material resources like property and credit, but also have been deprived of resources like education, market information and modern technology. All of these factors have negative implications for the type of enterprises that women are engaged in. The paper highlighted the various economic constraints faced by women in Nigeria, as a result of limitations imposed on them by nature and culture; It called for removal of gender-related obstacles in order to facilitate the creation of enterprises by women, as well as improving their general education, and entrepreneurial skills (Nwoye, 2013). The paper argued that gender imbalances in access to education and productive resources have important implications, not only for equity, but also for economic output, productivity, food security, fertility, and child welfare (Nwoye, 2013). It further recommended gender-specific activities and affirmative action, whenever women are in a particularly disadvantageous position (Nwoye, 2013). The paper concluded that mainstreaming gender into budget and policy design will provide women access to support services they require to develop the necessary confidence, explore alternative business ideas and entrepreneurial strategies that will stimulate, not only the Nigerian economy, but the people's way of life (Nwoye, 2013).

Ramadani et al's (2013) paper was about women entrepreneurs in Macedonia and looked at conditions for female entrepreneurship, perspectives for development and an array of problems that women entrepreneurs were facing. A survey was conducted during the period of December 2011 March 2012, to complement secondary sources. Respondents were asked about motives for starting a business, the size of the business they run, revenues, their family status, management problems, and necessary capabilities as perceived by them. They used Global Entrepreneurship Monitor (GEM) reports to compare the indicators of entrepreneurial activity between Republic of Macedonia and other countries in the region. The research study found that the women entrepreneurs faced a number of institutional and societal barriers in the operation of their businesses and were often motivated to start their businesses based on family responsibilities (Ramadani et al, 2013). 
Shankar (2013) looked globally at women's involvement in clean cooking value chains and found that it has been minimal. This explained that this is partly because of the multiple challenges faced by women that impede their capacity to effectively engage in the energy sector. To better discern genderspecific differences in involvement in the energy sector, the author conducted a randomized trial in Kenya to compare sales performance of newly trained male and female improved cookstove entrepreneurs and to test the effects of an agency-based empowerment training on business activity. A total of 257 entrepreneurs completed either a 4-day entrepreneurial training (control) or a 4-day empowerment training (intervention) and were followed for nearly 8 months documenting business activity and sales. The empowerment training led to more than doubling of sales for both genders (Shankar, 2013). In addition, participants in the intervention group were significantly more likely to demonstrate business commitment over time and nearly three times more likely to be higher sellers, controlling for gender and rural/urban locale (Shankar, 2013). Women outsold men by a margin of nearly 3 to 1 and were more likely to continue to pursue leads despite limited sales (Shankar, 2013). Nonactive participants (those selling 1 improved cookstove or less) were a larger percentage of the control group (72\%) than the intervention group (50\%), and more men were nonactive participants (65\% of men) compared with women (56\% of women). The research data showed that women can serve as active improved cookstove entrepreneurs in both urban and rural settings and that targeted agency-based empowerment training can significantly increase women's capacity to engage effectively within the improved cookstove value chain (Shankar, 2013).

Lindvert's 2015 paper empirically investigated how women entrepreneurs in Tanzania assess their accessibility to different external financial sources. The aim was to discuss financial preferences among the group of women entrepreneurs. The study was based on a unique database consisting of 114 firms, obtained by a questionnaire during 2009-2010. Differences between mean values on perceptions of financial sources were tested via a paired samples $t$-test. Overall, the empirical results provided support for the hypothesis that the sampled women entrepreneurs perceive semi-formal capital, such as loans from MFIs, SACCOS, ROSCAS and VICOBA, as the most accessible external capital (Lindvert, 2015). Governmental subsidies are ranked second, followed by informal capital, such as loans from family, friends and investors. As expected, loans from formal banks are ranked as the least accessible financing alternative (Lindvert, 2015). However, there are strong indications that the entrepreneurs in the study, if given a choice, would prefer external capital from formal sources, rather than semi-formal or informal capital (Lindvert, 2015). The authors suggested that the formal banks work to find ways to lower agency costs and thereby work for an inclusion of women entrepreneurs, and for the semi-formal financial actors to improve financial services in ways that better serve the entrepreneurs (Lindvert, 2015).

Roomi (2013) felt that in Pakistan, women entrepreneurs do not enjoy the same opportunities as men due to a number of deep-rooted discriminatory socio-cultural values and traditions. Furthermore, the author felt that these restrictions can be observed within the support mechanisms that exist to assist such fledgling businesswomen and that the economic potential of female entrepreneurs is not being realized as they suffer from a lack of access to capital, land, business premises, information technology, training and agency assistance (Roomi, 2013). Inherent attitudes of a patriarchal society are stated by the authors as having created formidable challenges (Roomi, 2013). The authors found that women also received little encouragement from some male family members, resulting in limited spatial mobility and a dearth of social capital (Roomi, 2013). The research suggested that in order to foster development, multi-agency cooperation is required. The media, educational policy makers and government agencies could combine to provide women with improved access to business development services and facilitate local, regional and national networks (Roomi, 2013). This would help integration of women entrepreneurs into the mainstream economy

Subramanian et al (2015) noted in a study completed earlier this year that the emergence of women entrepreneurs and their contribution the national economy is quite visible in India, pointing out that women in business is a recent phenomenon in India. The authors felt that the number of women entrepreneurs in that country has grown over a period of time, especially in the 1990s (Subramanian et al, 2015). They also announced that women entrepreneurs needed to be lauded for their increased utilization of modern technology, increased investment, finding a niche in the expect market, creating a sizable employment for others and setting the trend for other women entrepreneurs in the organized sector (Subramanian et al, 2015). The spread of education and increased awareness are aiding women of spread their wings in to areas which are hither to the monopoly of men has led to the number of 
women entrepreneurs in the field of engineering, electronics and energy being on the rise in India (Subramanian et al, 2015).

Welsh (2014) looked at Japanese women entrepreneurs and noted that their predominately familyowned firms were a growing economic segment in Japan. The purpose of the research was to investigate the characteristics of Japanese women entrepreneurs and their family firms, identify barriers and resources that affect their success. A customized long-term support system with strong connections between family business supporters and women business owners by both the governmental and private agencies was identified as important for further growth of Japanese women entrepreneurs (Welsh, 2014).

\section{ReSEARCH METHODOLOGY AND SAMPLE}

The results from this study consisted of women entrepreneurs surveyed in over 14 countries during the period August 2013 to August 2015. The questionnaire was prepared on the basis of a questionnaire used in a similar study in the United States in 2005 (see Smith-Hunter, 2006). The women entrepreneurs were contacted through a variety of sources, including entrepreneurship membership organizations and professors at the universities in their respective geographic areas, who work with women entrepreneurs. The women entrepreneurs were asked to complete the survey online. The women entrepreneurs in the current sample indicated that they were at least part owners of a registered company. Thus, this study does not include women in the informal sector of any of the countries' economies.

In total, up to 191 women entrepreneurs worldwide participated in this study, which provided a rich source of data for a research area that is often lacking in coverage. Among other things, the study looked at the general characteristics of the women entrepreneurs, as well as general characteristics of their businesses. More specifically, the general characteristics of the women entrepreneurs include three key variables that have been said to be critical to the success of an entrepreneurial venture. They are: human capital, network structures and financial capital.

The general characteristics assessed for the women entrepreneurs included demographic factors such as their age, education, marital status, number of children and whether the operate the businesses as sole proprietors or with a partner. The general characteristics of the businesses included what industries they operated in, what assistance if any they received with their bsuinesses, what problems they faced with the businesses and their level of financial success. Other questions looked at the amount of start up capital, what motivated them to start a business and what factors have led to their success.

\section{Results}

The international women's companies specialize in different areas of economic activity, but are found to be located primarily in the services industry. These businesses included: business consulting, information technology (IT), restaurant, calendar sales, event planning and hotel owner. The results regarding the dominance of women entrepreneurs in the service industry have been confirmed repeatedly in other studies. Namely, Jaccoud and Brassard (2003) while other studies on Australian women entrepreneurs have found them to be in non-traditional industries. Specifically, Bennett and Dann et al (2006) found the women entrepreneurs in that study concentrated in the manufacturing industry. While another study by Bennett and Dann (2000a and 2000b) found the older women entrepreneurs in that study concentration in the industry but the younger women entrepreneurs, those below 35 years old, to be in traditionally recognized male dominated industries.

The women in the current study also played a very important role as creators of new companies, since most $(66.8 \%)$ started their businesses themselves. This is followed by starting with a partner $(23.7 \%)$, see also table 1 . Most of the businesses in the current study remain primarily owned by the women (67.2\%, see table 2 ), with most $(55.6 \%)$ operating sole proprietorships, partnerships $(23.8 \%)$, followed by corporations (20.6\%), see also table 3. Conway and Sheridan (2005) also found that women entrepreneurs were often the original creators of their businesses, with $61.3 \%$ of the women in that study starting the businesses themselves. 


\section{Table 1}

\begin{tabular}{|l|c|c|}
\hline Did you: \\
\hline Answer Options & Response Percent & Response Count \\
\hline Start the business yourself? & $66.8 \%$ & 127 \\
\hline Buy the business from someone else? & $2.6 \%$ & 5 \\
\hline Star this business with a partner/partners? & $23.7 \%$ & 45 \\
\hline Inherit the business? & $2.1 \%$ & 4 \\
\hline Other (please specify) & $4.7 \%$ & 9 \\
\hline \multicolumn{2}{|l|}{ answered question } & $\mathbf{1 9 0}$ \\
\hline
\end{tabular}

Table 2

\begin{tabular}{|l|c|c|}
\hline Is this business owned solely by you? \\
\hline Answer Options & Response Percent & Response Count \\
\hline Yes & $67.2 \%$ & 127 \\
\hline No & $32.8 \%$ & 62 \\
\hline & answered question & $\mathbf{1 8 9}$ \\
\hline
\end{tabular}

Table 3

\begin{tabular}{|l|c|c|}
\hline What is the structure of this business? \\
\hline Answer Options & Response Percent & Response Count \\
\hline Partnership & $23.8 \%$ & 45 \\
\hline Corporation & $20.6 \%$ & 39 \\
\hline sole proprietorship & $55.6 \%$ & 105 \\
\hline \multicolumn{2}{|l|}{ answered question } & $\mathbf{1 8 9}$ \\
\hline
\end{tabular}

A considerable challenge facing women entrepreneurs worldwide is access to financial capital. The current results serve to reinforce that difficulty. For example, 35.1 percent of the women entrepreneurs did have difficulties obtaining financial capital when they started their businesses, see table 4. To finance their businesses, the women entrepreneurs thus primarily relied on their savings $(72.4 \%)$ for some of the start-up funds, see table 5. Start-up funds also included loans from family and friends (see tables 6 and 7, loan from previous business owner, table 8) and then money from credit card (table 9), bank loans (table 10) and partners, see Table 11.

Most of the women entrepreneurs had difficulty obtaining a bank loan (see table 13). This difficulty in obtaining start-up funds for a business was also documented by others, who also purported that the women in turn had to rely on their own personal funds for the start-up of their businesses (Bennett and Dann, 2000a; Conway and Sheridan, 2005; Lockett and Wright, 2002). The source of the startup funds mimic exactly the results of Bennett and Dann (2000) who also found that the Australian women entrepreneurs in that relied on personal savings and loans from family and friends.

Table 4

\begin{tabular}{|l|c|c|}
\hline When you started this business, did you have difficulties obtaining financial capital? \\
\hline Answer Options & Response Percent & Response Count \\
\hline Yes & $35.1 \%$ & 66 \\
\hline No & $64.9 \%$ & 122 \\
\hline \multicolumn{1}{|c|}{ answered question } & $\mathbf{1 8 8}$ \\
\hline
\end{tabular}

Table 5

\begin{tabular}{|l|c|c|}
\hline When you started this business where did you get your funds? & -Personal Savings- \\
\hline Answer Options & Response Percent & Response Count \\
\hline No & $27.4 \%$ & 52 \\
\hline Yes (Percentage) & $72.6 \%$ & 138 \\
\hline & answered question & $\mathbf{1 9 0}$ \\
\hline
\end{tabular}

Table 6

\begin{tabular}{|l|c|c|}
\hline When you started this business where did you get your funds? & \multicolumn{2}{c|}{-Gift from Family and Friends- } \\
\hline Answer Options & Response Percent & Response Count \\
\hline No & $89.4 \%$ & 161 \\
\hline Yes (Percentage) & $10.6 \%$ & 19 \\
\hline \multicolumn{2}{|c|}{ answered question } & $\mathbf{1 8 0}$ \\
\hline
\end{tabular}


Table 7

\begin{tabular}{|l|c|c|}
\hline When you started this business where did you get your funds? & -Loan from Family and Friends- \\
\hline Answer Options & Response Percent & Response Count \\
\hline No & $87.7 \%$ & 157 \\
\hline Yes (Percentage) & $12.3 \%$ & 22 \\
\hline \multicolumn{2}{|c|}{ answered question } & $\mathbf{1 7 9}$ \\
\hline
\end{tabular}

Table 8

\begin{tabular}{|l|c|c|}
\hline When you started this business where did you get your funds? & -Loan from previous owner- \\
\hline Answer Options & Response Percent & Response Count \\
\hline No & $97.7 \%$ & 171 \\
\hline Yes (Percentage) & $2.3 \%$ & 4 \\
\hline \multicolumn{2}{|c|}{ answered question } & $\mathbf{1 7 5}$ \\
\hline
\end{tabular}

Table 9

\begin{tabular}{|l|c|c|}
\hline When you started this business where did you get your funds? & -Credit card/personal loan- \\
\hline Answer Options & Response Percent & Response Count \\
\hline No & $77.1 \%$ & 138 \\
\hline Yes (Percentage) & $22.9 \%$ & 41 \\
\hline \multicolumn{2}{|c|}{ answered question } & $\mathbf{1 7 9}$ \\
\hline
\end{tabular}

Table 10

When you started this business where did you get your funds? -Bank Loan-

\begin{tabular}{|l|c|c|}
\hline Answer Options & Response Percent & Response Count \\
\hline No & $80.8 \%$ & 143 \\
\hline Yes (Percentage) & $19.2 \%$ & 34 \\
\hline \multicolumn{2}{|r|}{ answered question } & $\mathbf{1 7 7}$ \\
\hline
\end{tabular}

Table 11

\begin{tabular}{|l|c|c|}
\hline When you started this business where did you get your funds? & -Partners- \\
\hline Answer Options & Response Percent & Response Count \\
\hline No & $83.0 \%$ & 146 \\
\hline Yes (Percentage) & $17.0 \%$ & 30 \\
\hline \multicolumn{2}{|c|}{ answered question } & $\mathbf{1 7 6}$ \\
\hline
\end{tabular}

Table 12

When you started this business where did you get your funds? -Some other source-

\begin{tabular}{|l|c|c|}
\hline Ans wer Options & Response Percent & Response Count \\
\hline No & $66.7 \%$ & 66 \\
\hline Yes (Please explain) & $33.3 \%$ & 33 \\
\hline Percentage & $18.2 \%$ & 18 \\
\hline \multicolumn{2}{|l}{ answered question } & $\mathbf{9 9}$ \\
\hline
\end{tabular}

Table 13

\begin{tabular}{|l|c|c|}
\hline How difficult was it to get a bank loan? \\
\hline Answer Options & Response Percent & Response Count \\
\hline Not difficult at all & $41.2 \%$ & 47 \\
\hline Somewhat difficult & $24.6 \%$ & 28 \\
\hline Very difficult & $34.2 \%$ & 39 \\
\hline \multicolumn{2}{|c|}{ answered question } & $\mathbf{1 1 4}$ \\
\hline
\end{tabular}

The current study showed that most of the women entrepreneurs $(60.4 \%)$ had not been employed in previous businesses see also table 14. This is similar to other studies, which showed that most women entrepreneurs had not had previous employment experiences before their current venture (SmithHunter, 2006).

Table 14

\begin{tabular}{|l|c|c|}
\hline Were you ever or are you self-employed in any business(es) besides this one? \\
\hline Answer Options & Response Percent & Response Count \\
\hline Yes & $39.6 \%$ & 74 \\
\hline No & $60.4 \%$ & 113 \\
\hline \multicolumn{2}{|c|}{ answered question } & $\mathbf{1 8 7}$ \\
\hline
\end{tabular}




\section{Table 15}

\begin{tabular}{|c|c|c|c|c|}
\hline \multicolumn{5}{|c|}{$\begin{array}{l}\text { How much of each of the following kinds of experiences did you have before you became a business } \\
\text { owner? }\end{array}$} \\
\hline Answer Options & A lot & Some & None at all & Response Count \\
\hline Job in the same field as the business & 73 & 60 & 54 & 187 \\
\hline School education directly related to business & 65 & 59 & 64 & 188 \\
\hline Seminars, programs relevant to business & 44 & 81 & 59 & 184 \\
\hline Hobby, personal experience in same field & 63 & 69 & 51 & 183 \\
\hline Supervisory/management experience & 79 & 60 & 45 & 184 \\
\hline Accounting experience & 29 & 65 & 89 & 183 \\
\hline Sales/marketing experience & 56 & 66 & 61 & 183 \\
\hline
\end{tabular}

Most of the women business owners had a lot of business related experiences in different areas, table 15. A significant number of the women business owners had university educational experience (76.3\%), with a large portion of that percentage pursuing graduate school $(57.4 \%)$, see also table 16 . These results are slightly higher than others that have also shown women entrepreneurs to be a highly educated group; Wilson (2003) also found the Australian women entrepreneurs to be highly educated, while Conway and Sheridan (2005) found that Australian women entrepreneurs in their study had a Bachelors education $(50.6 \%)$ or a Graduate School education (22.5\%).

Table 16

\begin{tabular}{|l|c|c|}
\hline What is the highest grade of school that you have completed? \\
\hline Answer Options & Response Percent & Response Count \\
\hline None & $0.5 \%$ & 1 \\
\hline Elementary School & $1.1 \%$ & 2 \\
\hline High School/Vocational School & $12.1 \%$ & 23 \\
\hline College & $28.9 \%$ & 55 \\
\hline Graduate School & $57.4 \%$ & 109 \\
\hline \multicolumn{2}{|c|}{ answered question } & $\mathbf{1 9 0}$ \\
\hline
\end{tabular}

Table 17

\begin{tabular}{|l|c|c|}
\hline Which group best describes you? & Response Percent & Response Count \\
\hline Answer Options & $6.3 \%$ & 12 \\
\hline Black/African American & $67.7 \%$ & 128 \\
\hline White, not of Latino origin & $1.1 \%$ & 2 \\
\hline Latino & $19.6 \%$ & 37 \\
\hline Asian & $5.3 \%$ & 10 \\
\hline Other (please specify) & answered question & $\mathbf{1 8 9}$ \\
\hline \multicolumn{2}{|c|}{}
\end{tabular}

Most of the women entrepreneurs in this study were White (see table 17). A good percentage of the women in the research study are married $(71.4 \%)$, followed by the second largest percentage single/never married (14.8\%), see also table 18 . This relatively and surprisingly high marriage rate was somewhat confirmed in another study by NFWBO (2000), who found $74 \%$ of the women entrepreneurs in their study to be married and Instituto APOYO (2000) found a $61 \%$ marriage rate for the women entrepreneurs in their study. Most of the women entrepreneurs in the current study had children (71.7\%), with results indicating that they had 2.1 children on average, see table 19 . This result has also been confirmed in other research studies which also found the women entrepreneurs to primarily have children, averaging two children on average; NFWBO (2000) 2.4 children on average, NFWBO (1999) 2-3 children on average and Instituto APOYO (2000) -3 children on average.

Table 18

\begin{tabular}{|l|c|c|}
\hline What is your marital status? \\
\hline Answer Options & Response Percent & Response Count \\
\hline Married & $71.4 \%$ & 135 \\
\hline Separate/Divorced & $12.7 \%$ & 24 \\
\hline Widowed & $1.1 \%$ & 2 \\
\hline Single, never married & $14.8 \%$ & 28 \\
\hline \multicolumn{2}{|c|}{ answered question } & $\mathbf{1 8 9}$ \\
\hline
\end{tabular}


Table 19

\begin{tabular}{|l|c|c|}
\hline Do you have any children? \\
\hline Answer Options & Response Percent & Response Count \\
\hline No & $28.3 \%$ & 54 \\
\hline Yes (how many?) & $71.7 \%$ & 137 \\
\hline \multicolumn{2}{|c|}{ answered question } & $\mathbf{1 9 1}$ \\
\hline
\end{tabular}

Finally, $73.4 \%$ of the women entrepreneurs did not see going into business as their only alternative, see also Table 21.

Table 20

\begin{tabular}{|l|c|c|}
\hline Did you see going into business as your only alternative (in order to obtain an income) \\
\hline Answer Options & Response Percent & Response Count \\
\hline Yes & $24.6 \%$ & 46 \\
\hline No & $75.4 \%$ & 141 \\
\hline & answered question & $\mathbf{1 8 7}$ \\
\hline
\end{tabular}

Most of the women entrepreneurs received assistance from family $(65.1 \%)$ at the start-up stage of their businesses compared to the assistance they received from friends $(39.7 \%)$, see Table 21 . This majority help from family and friends declined as their businesses grew (40.5\%) and (20.2\%) respectively and it was less than at the start-up stage of their business, see Table 22 and 23. Assistance from family and friends in the operation of the business has also been reported in other studies (Conway and Sheridan, 2005; NFWBO, 2000; Instituto APOYO, 2000). This assistance from family, friends and acquaintances is critical in building an adequate network structure that is needed for successful entrepreneurship and was found to be lacking among rural Australian women entrepreneurs (Sutton, 2001; Alexander, 2001; Cachon, 2000, Chiste, 1996; Russell, 2007).

Table 21

\begin{tabular}{|l|c|c|}
\hline When you started this business did you obtain any assistance from (check all that apply) \\
\hline Answer Options & Response Percent & Response Count \\
\hline Friends & $39.7 \%$ & 58 \\
\hline Family & $65.1 \%$ & 95 \\
\hline Other (please specify) & $38.4 \%$ & 56 \\
\hline \multicolumn{2}{|c|}{ answered question } & $\mathbf{1 4 6}$ \\
\hline
\end{tabular}

Table 22

\begin{tabular}{|l|c|c|}
\hline Does your family assist you with the operation of the business? \\
\hline Answer Options & Response Percent & Response Count \\
\hline Yes & $40.5 \%$ & 77 \\
\hline No & $59.5 \%$ & 113 \\
\hline & answered question & $\mathbf{1 9 0}$ \\
\hline
\end{tabular}

Table 23

\begin{tabular}{|l|c|c|}
\hline Do your friends assist you with the operation of the business? \\
\hline Answer Options & Response Percent & Response Count \\
\hline Yes & $22.2 \%$ & 42 \\
\hline No & $77.8 \%$ & 147 \\
\hline \multicolumn{2}{|c|}{ answered question } & $\mathbf{1 8 9}$ \\
\hline
\end{tabular}

Table 24

\begin{tabular}{|l|c|c|}
\hline Does assistance for the operation of your business come from any other sources? \\
\hline Answer Options & Response Percent & Response Count \\
\hline No & $71.7 \%$ & 132 \\
\hline Yes (please specify) & $28.3 \%$ & 52 \\
\hline \multicolumn{2}{|l|}{ answered question } & $\mathbf{1 8 4}$ \\
\hline
\end{tabular}

Table 25

\begin{tabular}{|l|c|c|}
\hline Do you have any family members who are business owners? \\
\hline Answer Options & Response Percent & Response Count \\
\hline Yes & $56.8 \%$ & 105 \\
\hline No & $43.2 \%$ & 80 \\
\hline \multicolumn{2}{|c|}{ answered question } & $\mathbf{1 8 5}$ \\
\hline
\end{tabular}


For the women business owners, most of their family and friends owned businesses $(56.8 \%$ and $79.5 \%$ respectively), see also tables 25 and 26 . In addition, $41.3 \%$ had family working in the business and $27.4 \%$ had friends working in the business, see tables 27 and 28 . A surprising result was the membership organizations that the women business owners belonged to, with only $41.4 \%$ reporting that they belonged to such organizations, see also Table 29. Conway and Sheridan (2005) thought such membership in organizations was key to the success of Australian women entrepreneurs and felt further that the overwhelming benefits received from the membership organizations included: information, personal support, business contacts and referrals. The authors further concluded lack of such membership significantly limited their presence from local formal business networks. (Conway and Sheridan, 2005).

Table 26

\begin{tabular}{|l|c|c|}
\hline Do you have any friends who are business owners? \\
\hline Answer Options & Response Percent & Response Count \\
\hline Yes & $79.5 \%$ & 151 \\
\hline No & $20.5 \%$ & 39 \\
\hline \multicolumn{2}{|c|}{ answered question } & $\mathbf{1 9 0}$ \\
\hline
\end{tabular}

Table 27

\begin{tabular}{|l|c|c|}
\hline Do you have any family members that work in the business on a paid/non-paid basis? \\
\hline Answer Options & Response Percent & Response Count \\
\hline Yes & $41.3 \%$ & 78 \\
\hline No & $58.7 \%$ & 111 \\
\hline & answered question & $\mathbf{1 8 9}$ \\
\hline
\end{tabular}

Table 28

\begin{tabular}{|c|c|c|}
\hline \multicolumn{3}{|c|}{ Do you have any friends that work in the business on a paid/non-paid basis? } \\
\hline Ans wer Options & Response Percent & Response Count \\
\hline Yes & $27.4 \%$ & $\overline{52}$ \\
\hline No & $72.6 \%$ & 138 \\
\hline & answered question & 190 \\
\hline
\end{tabular}

Table 29

\begin{tabular}{|l|c|c|}
\hline Do you belong to any organizations that assist you in the operation of your business? \\
\hline Answer Options & Response Percent & Response Count \\
\hline No & $58.6 \%$ & 112 \\
\hline Yes (How many organizations do you belong to?) & $41.4 \%$ & 79 \\
\hline \multicolumn{2}{|c|}{ answered question } & $\mathbf{1 9 1}$ \\
\hline
\end{tabular}

Most of the women located their businesses in the home (51.3\%), see Table 30. These numbers are dissimilar to results by NFWBO (2000) and Instituto APOYO (2000) which found most of the women entrepreneurs in their studies also located outside the home (71\% and $76 \%$ respectively). Results that were echoed in a study by Chavan and Rakesh (1998) who also looked at female Australian women entrepreneurs.

Table 30

Is your business based in your home (as opposed to a separate office location)?

\begin{tabular}{|l|c|c|}
\hline Answer Options & Response Percent & Response Count \\
\hline Yes & $51.3 \%$ & 97 \\
\hline No & $48.7 \%$ & 92 \\
\hline & answered question & $\mathbf{1 8 9}$ \\
\hline
\end{tabular}

\section{CONCLUSION AND DISCUSSION}

In order to legitimately assess women entrepreneurs' position, one has to arc back to and look at the core component of that which is the woman, whose gender has resulted in its own tangential elements. To this end, we cannot therefore look at women entrepreneurs without looking at women in general and in turn acknowledge that awareness of the related dimensions of that latter element - health, education, political positioning, work and the legal components - must be understood and addressed in order to cater to the former group on an appropriate level. On a broader level, some key challenges remain in addressing women's position worldwide, they include, but are not limited to the following: 
- More focus on women's vulnerable health and health vulnerability status.

- The highly inequitable distribution.

- Gender discrimination in employment practices.

- Gender insensitivity of macroeconomic policies that do not address women's needs and vulnerable position.

- Lack of opportunity and power for women to influence these macro-economic policies.

- Lack of educational opportunities for women, especially and above the secondary level.

- The lack of recognition of the contribution of the macro economy of the informal, household and rural subsistence economies (to a nation's economy) where women are often concentrated.

Women located in the poorest countries in the world are also most likely to suffer adverse effects in the above areas (Berner et al, 2012) presents an appropriate platform to look at women's issues from various perspectives and to study women entrepreneurs worldwide, with the hope of making recommendations that can assist women to overcome other sectors through first obtaining economic independence. The framework that I am suggesting draws on data from a number of countries in seven regions of the world. As we move through this current century, good citizenship demands that we address women's position of independence and in so doing address their future place in the world's society.

\section{REFERENCES}

Achtenhagen, Leona, and Malin Tillmar. "Studies on Women's Entrepreneurship From Nordic Countries and Beyond." International Journal of Gender and Entrepreneurship 5.1 (2013): 4-16.

Alexander, Cynthia J. "Wiring the Nation! Including First Nations? Aboriginal Canadians and Federal E-government Initiatives."Journal of Canadian Studies 35.4 (2001): 277-296.

Al-Sadi, Ruqaya, Rakesh Belwal, and Raya Al-Badi. "Woman Entrepreneurship in the Al-Batinah region of Oman: An identification of the Barriers." Journal of International Women's Studies 12.3 (2013): 58-75.

Bahmani-Oskooee, M. "International Studies in Entrepreneurship."Women's entrepreneurship and economics: New perspectives, practices and policies. New York: Springer Verlag, 2012.12931299.

Bennett, Rebekah, and Susan Dann."The changing experience of Australian female entrepreneurs."Gender, work \& organization 7.2 (2000): 75-83.

Bennett, Rebekah, and Susan Dann. "Like mother like daughter? A Study of the Impact of Age on Entrepreneurial Women in Australia."Academy of Entrepreneurship Journal 6.1 (2000): 50-76.

Berner, Erhard, Georgina Gomez, and Peter Knorringa. "Helping a Large Number of People Become a Little Less Poor: The Logic of Survival Entrepreneurs." European Journal of Development Research 24.3 (2012): 382.

Browne, Katherine. "Female Entrepreneurship in the Caribbean: A Multisite, Pilot Investigation of Gender and Work." Human Organization 60.4 (2001): 326-42.

Cachon, Jean-Charles. "Aboriginal Entrepreneurship on Reserves: Some Empirical Data From Northern Ontario and Considerations Following the Supreme Court of Canada Decision on the Delgamuukw v. British Columbia appeal." Journal of Small Business \& Entrepreneurship 15.3 (2000): 2-14.

Cheraghi, Maryam, Zakia Setti, and Thomas Schott. "Growth-expectations Among Women Entrepreneurs: Embedded in Networks and Culture in Algeria, Morocco, Tunisia and in Belgium and France." International Journal of Entrepreneurship and Small Business 23.1-2 (2014): 191212.

Chiste, Katherine Beaty. Aboriginal Small Business and Entrepreneurship in Canada. North York, ON: Captus, 1996.

Conway, Lou, and Alison Sheridan."Women, Small Business and Regional Location."Rural Society 15.1 (2005): 55-76. 
Dana, L. "Indigenous Entrepreneurship: An Emerging Field of Research."International Journal of Business and Globalization 14.2 (2015): 158-169.

Dann, S., et al. "Female Entrepreneurship in Australia: Revisited." (2006): 1-7. This file was downloaded from: http://eprints. qut. edu. au/24956.

Diochon, M. "A Baseline Study of Entrepreneurship Among First Nations Women in the Atlantic Region."Journal of Small Business and Entrepreneurship 27.1 (2015): 89-112.

Fleming, Ann E., Lisa Petheram, and Natasha Stacey. "Australian Indigenous Women's Seafood Harvesting Practices and Prospects for Integrating Aquaculture."Journal of Enterprising Communities: People and Places in the Global Economy 9.2 (2015): 156-181.

Gallagher, B. and T.Lawrence."Entrepreneurship and Indigenous Identity: A Study of Identity Work by Indigenous Entrepreneurs in British Columbia."International Journal of Entrepreneurship and Small Business 17.4(2012): 395-414.

Gallgher, B. and M. Selman."Warrior Entrepreneur."American Indian Quarterly 39.1 (2015):73-94.

Hokari, Minoru. "Globalising Aboriginal Reconciliation: Indigenous Australians and Asian (Japanese) Migrants." Cultural Studies Review 9.2 (2013): 84-101.

Hoque, Mohammad Shamsul, Al Jamal Mustafa Shindaini, and Syed AQM Aktaruzzaman. "Women Entrepreneurs Development in Small and Medium Enterprises in Bangladesh: Exploring the Supportive Factors." Asian Journal of Research in Social Sciences and Humanities 5.6 (2015): 45-61.

Iakovleva, Tatiana, Marina Solesvik, and Anna Trifilova. "Financial Availability and Government Support for Women Entrepreneurs in Transitional Economies: Cases of Russia and Ukraine." Journal of Small Business and Enterprise Development 20.2 (2013): 314-340.

Instituto APOYO (2000), Women Business Owners in Argentina: A Source of Economic Growth. Prepared by The National Foundation for Women Business Owners.

Jaccoud, Mylène, and Renée Brassard. "The Marginalization of Aboriginal Women in Montréal."Not strangers in these parts: Urban Aboriginal peoples (2003): 131-145.

Lindvert, Marta, Darush Yazdanfar, and Håkan Boter. "Perceptions of Financial Sources Among Women Entrepreneurs in Tanzania." African Journal of Economic and Management Studies 6.2 (2015).

Lockett, Andy, Gordon Murray, and Mike Wright. "Do UK Venture Capitalists Still Have a Bias Against Investment in New Technology Firms." Research Policy 31.6 (2002): 1009-1030.

Mahmood, Rosli, and Norshafizah Hanafi. "Entrepreneurial Orientation and Business Performance of Women-owned Small and Medium Enterprises in Malaysia: Competitive Advantage as a Mediator." International Journal of Business and Social Science 4.1 (2013): 82-90.

Maru, Loice, and Razia Chemjor. "Microfinance Interventions and Empowerment of Women Entrepreneurs Rural Constituencies in Kenya."Research Journal of Finance and Accounting 4.9 (2013): 84-95.

Misango, Sedina B. and Orpha K. Ongiti. "Do Women Entrepreneurs Play a Role in Reducing Poverty? A Case in Kenya."International Review of Management and Business Research 2.1 (2013): 87-103.

Mutairi, Abdullah AL, and Fatema Fayez. "Factors Motivating Female Entrepreneurs in Kuwait."Journal of Applied Management and Entrepreneurship 20.1 (2015): 50.

National Foundation for Women Business Owners (1999), Women Business Owners in Sao Paulo, Brazil: A Summary of Key Issues, Prepared by Center for Women's Business Research and Underwritten by IBM.

National Foundation for Women Business Owners (2000), The Spirit of Enterprise: Latina Entrepreneurs in the United States, Prepared by Center for Women's Business Research and Underwritten by Wells Fargo.

N-Anantharaman, R. "Environmental, Personality, and Motivational Factors: A Comparison Study Between Women Entrepreneurs and Women Non Entrepreneurs in Malaysia." International Journal of Business and Management 8.13 (2013):15.

Nwoye, May. "Gender Responsive Entrepreneurial Economy of Nigeria: Enabling Women in a Disabling Environment." Journal of International Women's Studies 9.1 (2013):167-175. 
Odey, Mike. "Perspectives on the Growth of Small Scale Commodity Trade in Central Nigeria Up to the 1970s." ICIE 20153 rd International Conference on Innovation and Entrepreneurship: ICIE 2015. Academic Conferences Limited, 2015.

Ombati, Mokua. "Women Transcending "Boundaries" in Indigenous Peacebuilding in Kenya's Sotik/Borabu Border Conflict." Multidisciplinary Journal of Gender Studies 4.1 (2015): 637661.

Ramadani, Veland, et al. "Women Entrepreneurs in the Republic of Macedonia: Waiting for Directions." International Journal of Entrepreneurship and Small Business 19.1 (2013): 95-121.

Roomi, Muhammad Azam. "Entrepreneurial Capital, Social Values and Islamic Traditions: Exploring the Growth of Women-owned Enterprises in Pakistan." International Small Business Journal 31.2 (2013): 175-191.

Russell, Lynette. "Dirty Domestics and Worse Cooks": Aboriginal Women's Agency and Domestic Frontiers, Southern Australia, 1800-1850." Frontiers: A Journal of Women Studies 28.1 (2007): $18-46$.

Shankar, P. "Women Entrepreneur in India-Opportunities and Challenges." Abhinav-International Monthly Refereed Journal of Research in Management and Technology (2013): 2320-0073.

Shankar, Anita V., MaryAlice Onyura, and Jessica Alderman. "Agency-based Empowerment Training Enhances Sales Capacity of Female Energy Entrepreneurs in Kenya." Journal of Health Communication 20 (2015): 67-75.

Sutton, Peter. "The Politics of Suffering: Indigenous Policy in Australia Sincethe 1970s." Anthropological Forum. 11.2(2001).

Welsh, D. H., E.Memili, E.Kaciak, \& M. Ochi. Japanese Women Entrepreneurs: Implications for Family Firms. Journal of Small Business Management52.2(2014):286-305.

Wilson, Anne. "Self-employed Nurse Entrepreneurs Expanding the Realm of Nursing Practice: A Journey of Discovery." PhD diss., University of Adelaide, Australia, 2003. 